\title{
COPPER DESORPTION IN A SOIL WITH VARIABLE CHARGE
}

\author{
José Carlos Casagrande ${ }^{1 *}$; Camila Beig Jordão²; Luís Reynaldo Ferracciú Alleoni³; Otávio \\ Antônio de Camargo ${ }^{4}$ \\ ${ }^{1}$ UFScar/CCA - Depto. de Recursos Naturais e Proteção Ambiental, C.P. 153 - 13600-970 - Araras, SP - Brasil. \\ ${ }^{2}$ USP/ESALQ - Programa de Pós-Graduação em Solos e Nutrição de Plantas, C.P. 09 - 13418-900 - Piracicaba, \\ SP - Brasil. \\ ${ }^{3}$ USP/ESALQ - Depto. de Solos e Nutrição de Plantas. \\ ${ }^{4}$ IAC - Centro de Solos e Recursos Agroambientais, C.P. 28 - 3001-970 - Campinas, SP - Brasil. \\ *Corresponding author <bighouse@power.ufscar.br>
}

\begin{abstract}
Adsorption processes of heavy metals in soils have been more extensively studied than desorption, in spite of this latter process being related to nutrient bioavailability in the soil solution. Copper desorption from surface $(0-0.2 \mathrm{~m})$ and subsurface $(1.0-1.2 \mathrm{~m})$ samples of an Anionic Acrudox was studied at two $\mathrm{pH}$ values (4.5 and 7.5). Soil samples were incubated with $\mathrm{Cu}$ rates varying from 0 to $400 \mathrm{mg} \mathrm{kg}^{-1}, \mathrm{during}$ 4 and 12 weeks, in the presence of $\mathrm{CaCl}_{2}$ as support electrolyte at concentrations of 0.01 and $0.001 \mathrm{~mol} \mathrm{~L}^{-1}$. Complete soil adsorption of added $\mathrm{Cu}$ was observed at $\mathrm{pH} 7.5 \mathrm{in}$ all incubation periods, indicating that a $24 \mathrm{~h}-$ shaking period was enough to reach equilibrium and maximum adsorption. Copper adsorption varied with the incubation period and was much lower at $\mathrm{pH} 4.5$ than at $\mathrm{pH} 7.5$, after the 24 hour-incubation period. After 4 and 12 weeks, $\mathrm{Cu}$ adsorption values were higher and similar for all soil samples, irrespective of $\mathrm{pH}$ or depth of sampling. The effect of the incubation period on soil $\mathrm{Cu}$ adsorption surpassed the $\mathrm{pH}$ effect for all $\mathrm{Cu}$ rates. The hysteresis was expressive, suggesting that $\mathrm{Cu}$ enhances high-energy bonds with the soil colloids. Calcium chloride was not efficient in promoting native soil $\mathrm{Cu}$ desorption in the studied concentrations.

Key words: copper, desorption, ionic strength, $\mathrm{pH}$
\end{abstract}

\section{DESSORÇÃO DE COBRE EM SOLO COM CARGA VARIÁVEL}

\begin{abstract}
RESUMO: A adsorção de metais pesados aos solos é mais estudada do que sua dessorção. No entanto, o processo de dessorção está diretamente relacionado à disponibilidade dos elementos às plantas. A dessorção de cobre em amostras superficiais (0-0,2 m) e subsuperficiais (1,0-1,2 m) de um Latossolo Vermelho acriférrico foi estudada em dois valores de $\mathrm{pH}(4,5 \mathrm{e} \mathrm{7,5})$. Foram adicionados até $400 \mathrm{mg} \mathrm{kg}^{-1} \mathrm{de} \mathrm{Cu}$ em amostras incubadas por 4 e 12 semanas, tendo o $\mathrm{CaCl}_{2}$ como eletrólito suporte nas concentrações de 0,01 e $0,001 \mathrm{~mol} \mathrm{~L}^{-1}$. No $\mathrm{pH}$ mais elevado $(7,5)$, em todos os períodos de incubação, as amostras adsorveram praticamente todo o cobre adicionado, indicando que o tempo de $24 \mathrm{~h}$ de agitação para se atingir o equilíbrio foi suficiente para atingir a adsorção máxima. A adsorção de $\mathrm{Cu}$ variou com o tempo de incubação do elemento com o solo. No pH mais baixo (4,5), a adsorção foi bem menor após 24 h de incubação. Após 4 e 12 semanas, as adsorções foram elevadas e semelhantes para todas as amostras, independentemente da profundidade e do $\mathrm{pH}$. Para todas as doses estudadas, o efeito do tempo de incubação na adsorção de cobre pelo solo sobrepujou o efeito do $\mathrm{pH}$. O fenômeno de histerese foi expressivo, sugerindo que o $\mathrm{Cu}$ forma ligações de alta energia com os colóides do solo. O cloreto de cálcio não foi eficiente para dessorver cobre nativo do solo.

Palavras-chave: cobre, dessorção, força iônica, $\mathrm{pH}$
\end{abstract}

\section{INTRODUCTION}

The disposal of industrial residues and sewage sludges into Brazilian soils (Prado et at., 2002; Simonete \& Kiehl, 2002; Martins et al., 2003; Pires \& Mattiazzo, 2003) has been of considerable concern in recent years, mainly because of their possible high content in heavy metals, that may cumulate to toxic levels and constitute a potential hazard to plants, animals and mankind (Silveira et al., 1999; 2003). Adsorption-desorption reactions of metals at the soil colloidal surface affect their soil solution concentrations and, consequently, their availabilities to plants (Rodriguez-Rubio et al., 2003; Swift \& McLaren, 1991). The metal retention by soils can be explained by three mechanisms: specific adsorption, ionic exchange and precipitation (Rodriguez-Rubio et al., 2003).

Organic matter and $\mathrm{pH}$ are the factors that directly or indirectly affect the $\mathrm{Cu}$ bioavailability (RodriguezRubio et al., 2003; Yin et al., 2002). Organic radicals, as well as iron and aluminum oxides, have $\mathrm{OH}^{-}$sites with high potential for specific $\mathrm{Cu}$ adsorption (Guilherme et 
al., 1995; Silveira et al., 1999). In soils with $\mathrm{pH}$ lower than $2.5, \mathrm{Cu}$ competes with protons for adsorption sites. However, at $\mathrm{pH}$ above 4.5 , most charged sites are bound to $\mathrm{Cu}$, due to the decreasing proton competition (Grimm et al., 1991). Between $\mathrm{pH} 4.0$ to 6.0, $\mathrm{Fe}$ and $\mathrm{Al}$ oxides are the main cause of metal fixation and solubilization (Cavallaro \& McBride, 1984). In relation to the soil native copper, Hogg et al. (1993) observed small desorption after a two-hour equilibrium, what evidenced low rate of $\mathrm{Cu}$ reaction with the soil colloids.

The objectives of this research were to evaluate the initial reaction time of $\mathrm{Cu}$ with an Anionic Acrudox soil during desorption process, the necessary shaking period for the native and added copper to reach equilibrium, the observation of the hysteresis phenomenon during the adsorption/desorption processes, and the desorption variation with the soil $\mathrm{pH}$.

\section{MATERIAL AND METHODS}

Surface (0 and $0.2 \mathrm{~m})$ and subsurface $(1.0$ and $1.2 \mathrm{~m}$, in the highest expression of B-horizon) soil samples were collected from an Anionic Acrudox (LVwf), at the municipal district of Ribeirão Preto, State of São Paulo, Brazil $\left(21^{\circ} 17^{\prime} \mathrm{S}, 47^{\circ} 81^{\prime} \mathrm{W}\right)$. Soil samples were sieved through a 2-mm screen, and two portions of 1.0 $\mathrm{kg}$, air-dried soil were taken and thoroughly mixed with enough calcium carbonate $\left(\mathrm{CaCO}_{3}\right)$ or hydrochloric acid $(\mathrm{HCl})$ to obtain $\mathrm{pH}$ values close to 4.5 and 7.5 and mimic soil conditions of acidity and alkalinity, respectively. These samples were incubated with $25 \%(\mathrm{~m} / \mathrm{m})$ of water, circa the soil's field capacity, at constant $\mathrm{pH}$. Samples were their air-dried and sieved again through a $2-\mathrm{mm}$ screen.

Chemical and physical analyses (Table 1) were performed according to Camargo et al. (1986): organic matter was oxidized with potassium dichromate to obtain organic carbon; $\mathrm{pH}$ was determined in 0.01 water using 1:2.5 (soil:solution) ratio; the zero point of salt effect (ZPSE) was obtained by titration with $\mathrm{H}^{+}$and $\mathrm{OH}^{-}$in three concentrations of $\mathrm{KCl}$, according to Alleoni \& Camargo (1994); oxides concentrations were determined after sulfuric acid digestion; "free" iron was evaluated after dithionite reduction and sodium citrate reaction; poorlycrystallized iron and aluminum were dissolved in oxalic acid and their ammonium salts, and clay contents determined by the pipette method.

\section{Native $\mathrm{Cu}$ adsorption and desorption}

Soil samples previously incubated with either $\mathrm{CaCO}_{3}$ or $\mathrm{HCl}$ were evaluated regarding native $\mathrm{Cu}$ desorption. The procedure to evaluate the ionic strength effect on $\mathrm{Cu}$ desorption was: $2 \mathrm{~g}$ of soil sample were transferred to 50-mL polyethylene tubes and $20 \mathrm{~mL}$ of 0.01 and 0.001 mol L ${ }^{-1} \mathrm{CaCl}_{2}$ solutions were added (Hogg et al., 1993; Zhu \& Alva, 1993). The soil was mixed with the solution and the suspension was left steady during $24 \mathrm{~h}$ to reach equilibrium, as recommended by Gupta \& Mackay (1966). The suspension was shaken for either 2, 4 or 8 hours to evaluate $\mathrm{Cu}$ desorption. Since no effect of the shaking period was observed (data not shown), the period of $2 \mathrm{~h}$ was chosen. At least ten desorption procedures per each sample were done, as follows: after each 2 -h period, the soil:solution suspension was centrifuged at 4,000 rpm, and the supernatant was filtered through blue ribbon paper filter and collected for subsequent $\mathrm{Cu}$ determination. The soil in the tube was resuspended in new electrolyte solution. All procedure for the desorbed $\mathrm{Cu}$ determination was then repeated for ten consecutive times. The $\mathrm{Cu}$ contents in the collected supernatant solutions were determined by atomic absorption spectrometry, and the accumulated quantity of desorbed $\mathrm{Cu}$ was calculated by adding up the $\mathrm{Cu}$ contents in each equilibrium solution. All determinations were made in duplicates.

\section{Native Cu extracted with DTPA}

The native copper was also extracted with a $0.005 \mathrm{~mol} \mathrm{~L}^{-1}$ DTPA solution, following routine extracting procedure for the determination of available $\mathrm{Cu}$ for fertilizer recommendation purposes (Raij et al., 2001). All determinations were made in duplicates, and compared to the accumulated quantities of native $\mathrm{Cu}$ determined by the desorption procedure described above.

\section{Adsorption and desorption of added $\mathrm{Cu}$}

The added $\mathrm{Cu}$ desorption, by adding $\mathrm{CuCl}_{2}$, was proceeded in soil samples with two $\mathrm{pH}$ values $(4.5$ and 7.5) and evaluated during three periods of soil/ $\mathrm{Cu}$ incubation for either 24 hours, according to Gupta \& Mackay (1966), 4 or 12 weeks (Hogg et al., 1993), with moisture content kept at $25 \%$ (soil field capacity). Hogg et al. (1993), studying $\mathrm{Cu}$ adsorption in ten soils from New Zealand, concluded that a period of incubation of 12 weeks was adequate, because adsorption was very low afterwards.

Table 1 - Chemical and physical characteristics of the Anionic Acrudox.

\begin{tabular}{|c|c|c|c|c|c|c|c|c|c|c|c|c|}
\hline Depth & $\mathrm{C}$ & $\mathrm{pH} \mathrm{H}_{2} \mathrm{O}$ & $\Delta \mathrm{pH}$ & ZPSE & SSA & $\mathrm{Ki}$ & $\begin{array}{c}\mathrm{Fe}_{2} \mathrm{O}_{3} \\
\text { Total }\end{array}$ & Fed & $\mathrm{Fe}_{\mathrm{ox}}$ & $\begin{array}{l}\mathrm{Al}_{2} \mathrm{O}_{3} \\
\text { Total }\end{array}$ & $\mathrm{Al}_{\mathrm{ox}}$ & Clay \\
\hline $\mathrm{m}$ & $\mathrm{g} \mathrm{kg}^{-1}$ & & & & $\mathrm{~m}^{2} \mathrm{~g}^{-1}$ & & -...... & 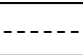 & $-\mathrm{g} \mathrm{k}$ & $\ldots$ & $\ldots$ & $\cdots$ \\
\hline $0-0.2$ & 20.0 & 6.4 & -0.9 & 3.3 & 38 & 0.93 & 320 & 160 & 13 & 200 & 10 & 60 \\
\hline $1.0-1.2$ & 5.0 & 5.3 & 0.3 & 6.3 & 24 & 0.87 & 240 & 170 & 9 & 200 & 7 & 64 \\
\hline
\end{tabular}

ZPSE = Zero point of salt effect; SSA = specific surface area; Fed = "free" iron; $\mathrm{Fe}_{\mathrm{ox}}=$ poorly-crystallized; $\mathrm{Al}_{\mathrm{ox}}=$ "free" aluminum 
The quantities of $\mathrm{Cu}$ added to the soil for adsorption and 24 hours later for desorption were 5, 20, 50, 100, 200,400 , and $600 \mathrm{mg} \mathrm{kg}^{-1}$. Treatments correspondent to the 4 and 12-week incubation periods received the intermediary rates of 20,100 and $400 \mathrm{mg} \mathrm{kg}^{-1}$. The soil $\mathrm{Cu}$ adsorption was evaluated after shaking during 24 hours, by subtracting the $\mathrm{Cu}$ determined in the equilibrium solution from the $\mathrm{Cu}$ initially added. After the 24h-shaking period, at least ten $2 \mathrm{~h}$-periods of desorption were evaluated for each sample, using 0.01 and $0.001 \mathrm{~mol} \mathrm{~L}^{-1} \mathrm{CaCl}_{2}$ solutions, following the same procedure described for the native $\mathrm{Cu}$ desorption determination. After centrifugation and separation of the supernatant solution, the soil was resuspended in new electrolyte solution, restarting the procedure of $\mathrm{Cu}$ desorption determination, which was repeated ten times. The equilibrium solutions collected were analyzed for $\mathrm{Cu}$ by atomic absorption spectrometry. All determinations were run in duplicates.

\section{RESULTS AND DISCUSSION}

\section{$\mathrm{Cu}$ adsorption}

The Anionic Acrudox studied is rich in iron and aluminum oxides (Table 1). The oxides as well as the organic matter define the magnitude of the specific $\mathrm{Cu}$ adsorption (Silveira et al., 2002; Silveira \& Alleoni, 2003; Rodriguez-Rubio et al., 2003) and thus, the specific $\mathrm{Cu}$ adsorption is little affected by the ionic strength variation (Zelazny et al., 1996). Such considerations indicate that $\mathrm{Cu}$ is adsorbed as an inner-sphere complex and does not participate of the soil exchange complex. The ZPSE in the soil surface layer was 3.3, with negative charge balance in both studied $\mathrm{pH}$ values, whereas in depth, the ZPSE was 6.3, with positive charge balance at the lower $\mathrm{pH}$ value (4.5).

Oxisols with acric properties have effective cation exchange capacity (ECEC) lower than $15 \mathrm{mmol} \mathrm{kg}^{-1}$ of clay and the $\mathrm{pH}$ of B-horizon $\mathrm{pH}$ measured in $1.0 \mathrm{~mol} \mathrm{~L}^{-1}$ $\mathrm{KCl}$, higher than or equal to 5.0, in a $1.5 \mathrm{~m}$ depth (Soil Survey Staff, 1990). Such soils are common in tropical regions and predominate over a wide area in the North of the State of São Paulo, Brazil, where they are intensively cultivated. In the Anionic Acrudox B-horizon, the difference between the zero point of charge (ZPC) and $\mathrm{pH}$ is small. In many cases, the $\mathrm{ZPC}$ value surpasses the $\mathrm{pH}$ value, giving rise to a positive charge balance to the soil, that becomes predominantly an anion exchanger. This charge reversion phenomenon almost always occurs in soil depths greater than $0.5 \mathrm{~m}$, because in such situation the

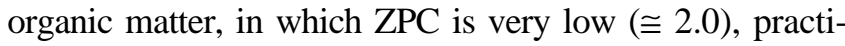
cally has no effective action (Uehara, 1988). As a matter of fact, Silveira \& Alleoni (2003), studying an Anionic Acrudox, observed that surface horizon adsorbed higher $\mathrm{Cu}$ amounts than the subsurface horizon, thus evidencing the influence of soil organic matter upon this metal adsorption.
Copper adsorption varied with the soil incubation period. At higher $\mathrm{pH}$ values (7.5), in all incubation periods, adsorption was similar for both samples and corresponded practically to all added $\mathrm{Cu}$ (Figures 1 and 2). The 24h-shaking period to reach equilibrium was thus enough to attain the maximum adsorption. Rodriguez-Rubio et al. (2003), also found significant $\mathrm{Cu}$ adsorption in Spanish soils with $\mathrm{pH} 7.8$, using $24 \mathrm{~h}$-shaking period to reach equilibrium. The high $\mathrm{Cu}$ adsorption at higher $\mathrm{pH}$ was similar to that observed by Ponizovsky et al. (2001) in a Chernozen under forest and a Podzol, both in Russian territory. At lower $\mathrm{pH}$ (4.5), $\mathrm{Cu}$ adsorption was lower only after 24 h-incubation; however, past 4 and 12 weeks, both soil samples showed similar $\mathrm{Cu}$ adsorption values, irrespective of sampling depth or $\mathrm{pH}$.

Considering that the Anionic Acrudox (LVwf) shows variation in charge balance as $\mathrm{pH}$ changes, presenting more positive charges with increasing external acidity, the decreased amount of negative charges at lower $\mathrm{pH}$ values was seemingly not enough to adsorb all $\mathrm{Cu}$ during the 24-hour-incubation period. Nevertheless, the $\mathrm{Cu}-$ adsorption evolved to higher values after 4- and 12-weekincubation. Such slow $\mathrm{Cu}$ adsorption reaction with soil colloids has already been noticed by Barrow (1985) and Hogg et al. (1993), especially for organic colloids.

In the range of the $\mathrm{Cu}$ application rates, the incubation period effect on soil $\mathrm{Cu}$-adsorption surpassed the $\mathrm{pH}$ effect. Although the difference observed between the surface and subsurface layers ZPSE values (3.3 and 6.3, respectively) (Table 1), the latter with a positive balance of charge at $\mathrm{pH} 4.5$, the soil $\mathrm{Cu}$-adsorption values were not different when soil samples were incubated for 4 and 12 weeks (Figure 1). Thereafter, the contact period between $\mathrm{Cu}$ and soil must be taken into account in adsorption studies of this metal by soil colloids, as previously appointed by Nascimento et at. (2003) for soils fertilized with $\mathrm{Cu}$.

\section{Desorption of native $\mathrm{Cu}$}

The amount of DTPA-extracted $\mathrm{Cu}$ decreased as soil $\mathrm{pH}$ increased, as already observed by Camargo et al. (1982) in 24 surface soil samples of the State of São Paulo, Brazil. As a matter of fact, DTPA had been described as an efficient soil $\mathrm{Cu}$ extracting solution for the purpose of fertilization recommendations for several crops (Abreu et al., 1996). Calcium chloride was inefficient to evaluate native $\mathrm{Cu}$ desorption by the Anionic Acrudox in the used concentrations. In spite of not showing selectivity in relation to calcium, $\mathrm{Cu}$ seems to be more tightly bound to the soil than by a simple ionic exchange.

The procedures of desorption extracted very little native soil $\mathrm{Cu}$ at both $\mathrm{pH}$ values, irrespective of shacking periods and $\mathrm{CaCl}_{2}$ concentrations. Hogg et al. (1993), using $0.01 \mathrm{~mol} \mathrm{~L}^{-1} \mathrm{Ca}\left(\mathrm{NO}_{3}\right)_{2}$, solution, also extracted small cumulative quantities of native copper desorbed of ten 

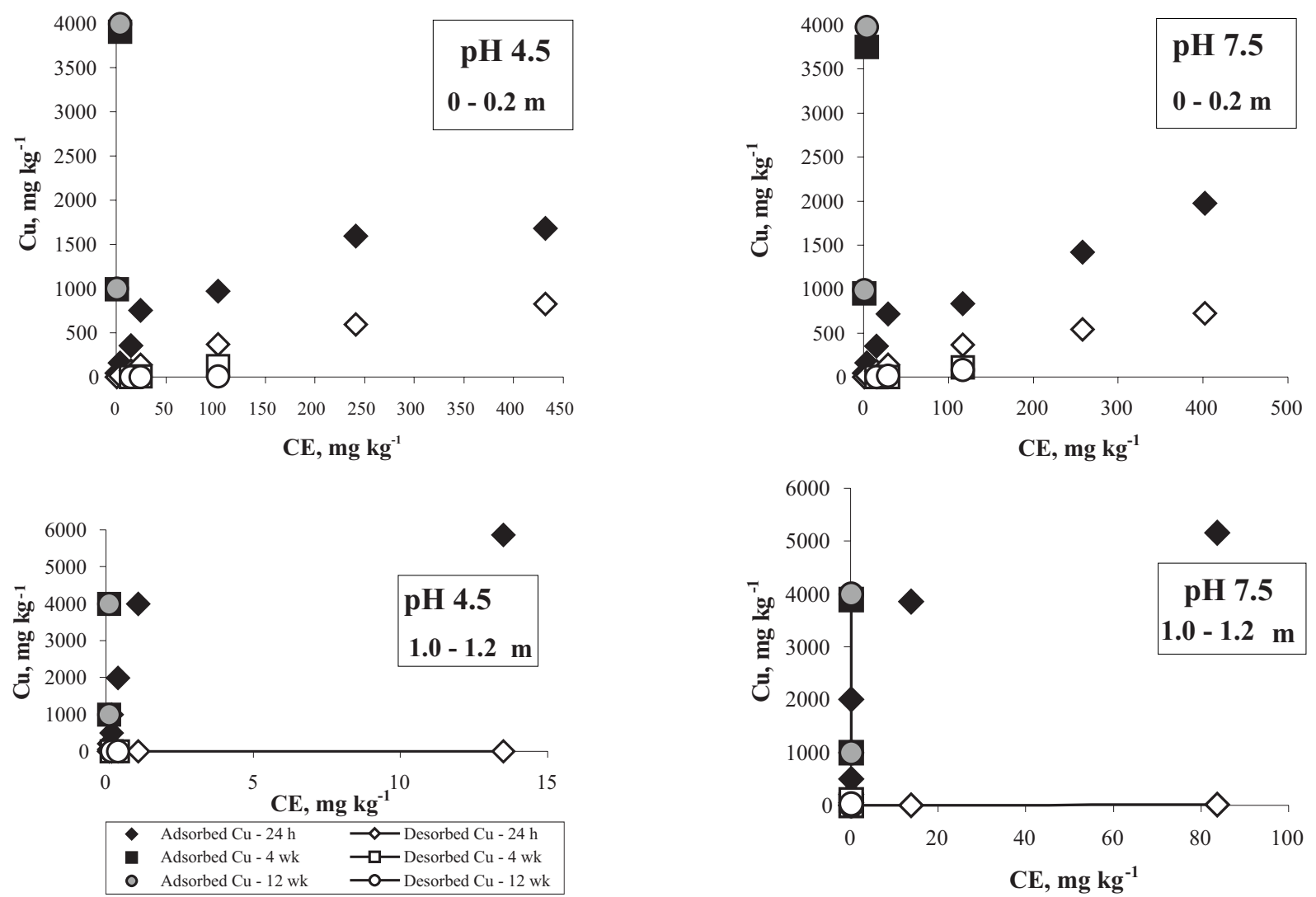

Figure 1 - Adsorption and desorption of $\mathrm{Cu}$ added to surface and subsurface samples, of an Anionic Acrudox incubated during 24 hours, 4 and 12 weeks, at $\mathrm{pH} 4.5$ and 7.5 , using $0.01 \mathrm{~mol} \mathrm{~L}^{-1} \mathrm{CaCl}_{2}$ solution $(\mathrm{CE}=$ concentration in the equilibrium solution).
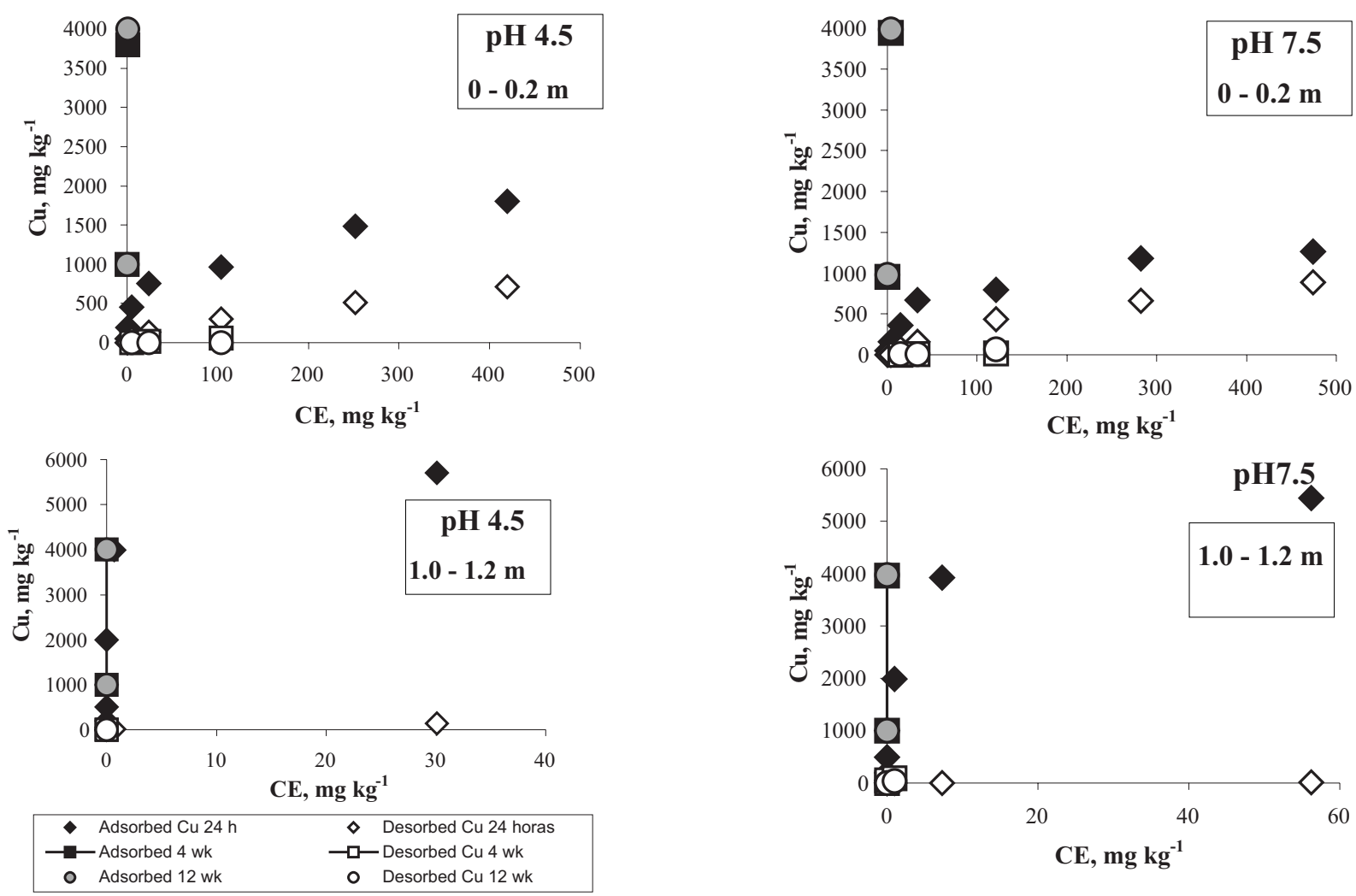

Figure 2 - Adsorption and desorption of $\mathrm{Cu}$ added to soil samples collected from the surface and in depth, and incubated during 24 hours, 4 and 12 weeks, with $\mathrm{pH} 4.5$ and 7.5, using $0.001 \mathrm{~mol} \mathrm{~L}^{-1} \mathrm{CaCl}_{2}$ solution $(\mathrm{CE}=$ concentration in the equilibrium solution). 
soils from New Zealand, with a variation of 0.087 to $0.171 \mathrm{mg} \mathrm{kg}^{-1}$. DTPA extracted large amounts of available copper in the surface layers, mainly at low $\mathrm{pH}$ values, and under limits set by Raij et al. (1997). For the studied $\mathrm{pH}$ values, the quantities of extracted copper ranged from 7.3 to $4.6 \mathrm{mg} \mathrm{kg}^{-1}$ in the surface, and from 1.5 to $0.3 \mathrm{mg} \mathrm{kg}^{-1}$ in the subsurface samples (Table 2).

\section{Desorption of added $\mathrm{Cu}$}

Each soil sample was desorbed at least ten times, and the desorption procedure was interrupted when desorbed $\mathrm{Cu}$ quantities were lower than $0.01 \mathrm{mg} \mathrm{kg}^{-1}$ of soil.

Table 2 - Variation in the $\mathrm{Cu}$ contents in the desorption solution and DTPA-extracting solution, with $\mathrm{pH}$ values, in soil samples from an Anionic Acrudox.

\begin{tabular}{lccc}
\hline Depth & pH & Desorbed Cu & DTPA - Cu \\
\hline $\mathrm{m}$ & & $\cdots \ldots \ldots \ldots$ & $\mathrm{mg} \mathrm{kg}^{-1}$ \\
$0-0.2$ & 4.8 & 0.1 & 7.3 \\
& 6.6 & 0.01 & 6.1 \\
& 6.9 & 0 & 4.6 \\
& 7.7 & 0 & 4.7 \\
$1.0-1.2$ & 4.2 & 0.01 & 1.5 \\
& 5.5 & 0 & 1.4 \\
& 6.9 & 0 & 1.2 \\
& 7.7 & 0 & 0.3 \\
\hline
\end{tabular}

It was recorded copper desorption of $17 \%$ in the surfaceand of $23 \%$ in the subsurface-soil samples, in both support electrolyte concentrations, for the added $\mathrm{Cu}$ rate of $100 \mathrm{mg} \mathrm{kg}^{-1}$ at $\mathrm{pH} 4.5$ and without incubation, whereas at $\mathrm{pH} 7.5$, desorption was practically null. The quantity of desorbed copper increased as $\mathrm{pH}$ decreased, since the number of positive charges increased, as was already noticed by Temminghoff et al. (1994) and Wang et al. (2003). At low $\mathrm{pH}, \mathrm{Cu}$ might be adsorbed in the exchangeable form, while at higher $\mathrm{pH}$, specific adsorption might occur (Wang et al., 2003). For soil incubation periods of 4 and 12 weeks, desorption values were very low, reaching up to 0.1 to $0.3 \%$ of the total absorbed $\mathrm{Cu}$, respectively. When $\mathrm{pH}$ values were higher, in all incubation periods, desorption was practically null (Figures 1, 2 and 3 ).

Cumulative desorption evidences strong interaction between $\mathrm{Cu}$ and soil colloids, and the period of contact plays an important role (Figure 3). The largest desorbed quantity occurred after a $24 \mathrm{~h}$ incubation, and the smallest after a 12-week period. These results are similar to those reported for $\mathrm{Cu}$ desorption by goethite (Padmanabham, 1983a, b) and by soils (Lehmann \& Harter, 1984). In both papers, the longer the period between the initial adsorption and desorption, the higher the quantity of copper irreversibly adsorbed. The slow $\mathrm{Cu}$ adsorption reactions into the soil are responsible for the re-

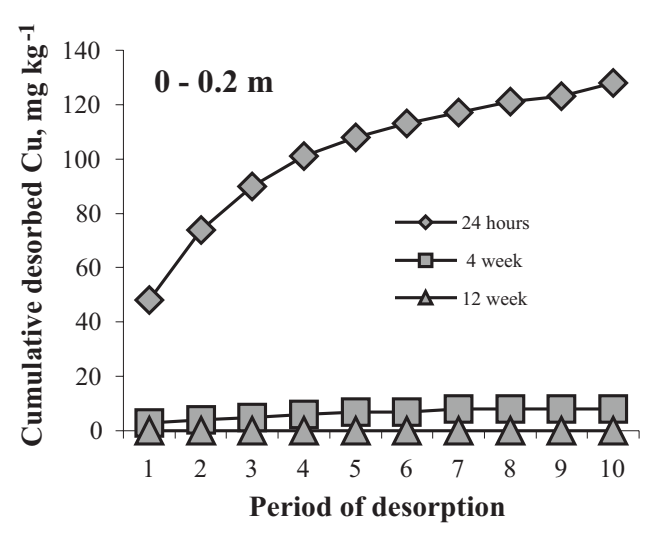

$0.01 \mathrm{~mol} \mathrm{~L}^{-1}$

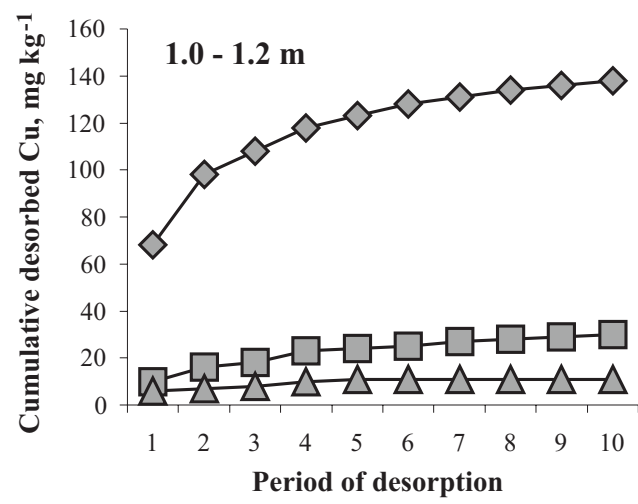

$0.001 \mathrm{~mol} \mathrm{~L}^{-1}$
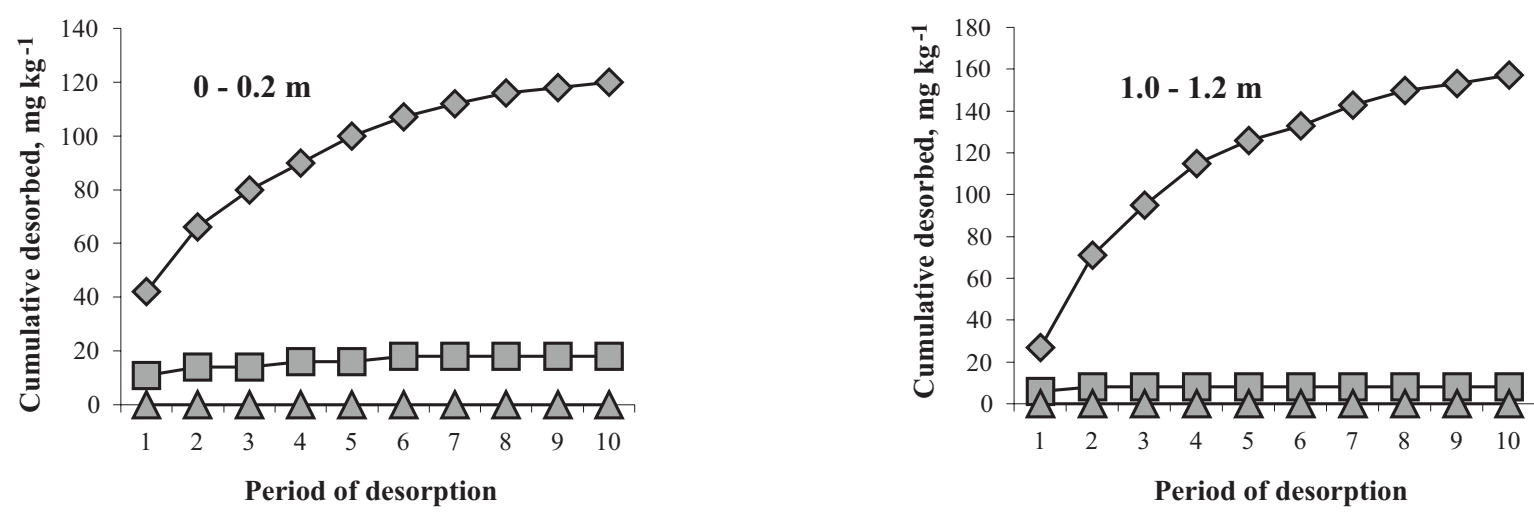

Figure 3 - Cumulative desorption of added $\mathrm{Cu}\left(100 \mathrm{mg} \mathrm{dm}^{-3}\right)$, incubated surface and subsurface soil samples of an Anionic Acrudox, during 24 hours, 4 and 12 weeks, for $\mathrm{pH} 4.5$, using 0.01 and $0.001 \mathrm{~mol} \mathrm{~L}^{-1} \mathrm{CaCl}_{2}$ solutions.

Sci. Agric. (Piracicaba, Braz.), v.61, n.2, p.196-202, Mar./Apr. 2004 
duced possibility of desorption of this element to the soil solution (McLaren et al., 1983 and Hogg et al., 1993) with subsequent implications regarding its availability to plants in long terms (Hogg et al., 1993).

The hysteresis phenomenon was expressive, as already observed by Padmanabham (1983a, b) and Wu et al. (1999), suggesting that $\mathrm{Cu}$ makes high-energy bonds with soil colloids. The first author considered the presence of two adsorption sites in the goethite surface, one of fast and the other of slow desorbing fraction; the other authors suggested that specific adsorption predominantly occurred by soil colloids.

As general conclusions, $\mathrm{pH}$ affected $\mathrm{Cu}$ adsorption and desorption only at time zero (24 h) of incubation. After 4 and 12 weeks of incubation, adsorption was about the same for the tested $\mathrm{pH}$ values. Calcium chloride was inefficient in desorbing native soil copper.

\section{ACKNOWLEDGEMENTS}

The authors acknowledge the financial support granted to this research by 'Fundação de Amparo à Pesquisa do Estado de São Paulo' (FAPESP).

\section{REFERENCES}

ABREU, C.A.; RAIJ, B. van; ABREU, M.F.; SANTOS, W.R.; ANDRADE, J.C. Efficiency of multinutrient extractants for the determination of available copper in soils. Communications in Soil Science and Plant Analysis, v.27, p.763-771, 1996.

ALLEONI, L.R.F.; CAMARGO, O.A. Ponto de efeito salino nulo de Latossolos ácricos. Revista Brasileira de Ciência do Solo. v.18, p.175$180,1994$.

BARROW, N.J. Reactions of anions and cations with variable-charge soils. Advances in Agronomy, v.38, p.183-230, 1985.

CAMARGO, O.A.; VALADARES, J.M.A.S.; DECHEM, A.R. Efeitos do $\mathrm{pH}$ e da incubação na extração de manganês, zinco, cobre e ferro do solo. Revista Brasileira de Ciência do Solo, v.6, p.83-88, 1982.

CAMARGO, O.A.; MONIZ, A.C.; JORGE, J.A.; VALADARES, J.M.S. Métodos de análise química, mineralógica e física de solos do Instituto Agronômico de Campinas. Campinas: IAC, 1986. 94 p. (Boletim Técnico, 106).

CAVALLARO, N.; McBRIDE, M.B. Zinc and Copper sorption and fixation by an acid soil clay: effect of selective dissolutions. Soil Science Society of America Journal, v.48, p.1050-1054, 1984.

GRIMM, D.M.; AZARRAGA, L.V; CARREIRA, L.A; SUSETYO, W. Continuous multiligand distribution model used to predict the stability constant of $\mathrm{Cu}$ (II) metal complexation with humic material from fluorescence quenching data. Environmental Science \& Technology, v.25, p.1427-1431, 1991 .

GUILHERME, L.R.G.; LIMA, J.M.; ANDERSON, S.J. Efeito do fósforo na adsorção de cobre em horizontes A e B de Latossolos do Estado de Minas Gerais. In: CONGRESSO BRASILEIRO DE CIÊNCIA DO SOLO, 25., Viçosa, 1995. Anais. Viçosa: SBCS, 1995.p.316-318.

GUPTA, U.C; MACKAY, D.C. Procedure for determination of exchangeable copper and molybdenum in podzol soils. Soil Science, v.101, p.93-97, 1966.

HOGG, D.S.; McLAREN, R.G.; SWIFT, R.S. Desorption of copper from some New Zealand soils. Soil Science Society of America Journal, v.57, p.361-366, 1993.

LEHMANN, R.G.; HARTER, R.D. Assessment of copper soil bond strength by desorption kinetics. Soil Science Society of American Journal, v.48, p.769-772, 1984.
MARTINS, A.L.C.; BATAGLIA, O.C.; CAMARGO, O.A. Cooper, nickel and zinc phytoavailability in an oxisol amended with sewage sludge and liming. Scientia Agricola, v.60, p.747-754, 2003.

McLAREN, R.G.; WILLIANS, J.G.; SWIFT, R.S. Some observations on the desorption and distribution behavior of copper with soil components. Journal Soil Science, v.34, p.325-331, 1983.

NASCIMENTO, C.W.A.; FONTES, R.L.F.; MELICIO, A.C.F.D. Copper availability as related to soil cooper fractions in oxisols under liming. Scientia Agricola. v.60, p.167-173, 2003.

PADMANABHAM, M. Comparative study of the adsorption - desorption behaviour of copper (II), zinc (II), cobalt (II) and lead (II) at the goethite -solution interface. Australian Journal of Soil Research, v.21, p.515525, 1983a.

PADMANABHAM, M. Adsorption-desorption behaviour of copper (II) at the goethite-solution interface. Australian Journal of Soil Research, v.21, p.309-320, 1983 b.

PIRES, A.M.M.; MATTIAZO, M.E. Biosolids conditioning and the availability of $\mathrm{Cu}$ and $\mathrm{Zn}$ for rice. Scientia Agricola, v.60, p.161-166, 2003.

PONIZOVSKY, A.A.; STUDENIKINA, T.A.; MIRONENKO, E.V.; KINGER, W.L. Copper(II) retencion by Chernozem, Gray Forest and Dernovo-Podzolic soils: $\mathrm{pH}$ effect and cation balance. Soil Science, v.166, p.239-248, 2001.

PRADO, R.M.; FERNANDES, F.M.; NATALE, W. Calcário e escória de siderurgia avaliados por análise foliar, acúmulo, e exportação de macronutrientes em cana-de-açúcar. Scientia Agricola, v.59, p.129-135, 2002.

RAIJ, B. van; CANTARELLA, H.; QUAGGIO, J.A.; FURLANI, A.M.C. Recomendações de adubação e calagem para o Estado de São Paulo. Campinas: IAC, 1997. 285 p. (Boletim Técnico, 100).

RAIJ, B. van; ANDRADE, J.C.; CANTARELLA, H.; QUAGGIO, J.A. Análise química para avaliação da fertilidade de solos tropicais. Campinas: IAC, 2001. 285p.

RODRIGUEZ-RUBIO, P.; MORILLO, E.; MADRID, L.; UNDABEYTIA, T.; MAQUEDA, C. Retention of copper by calcareous soil and its textural fractions influence of amendment with two agroindustrial residues. European Journal of Soil Science, v.54, p.401-409, 2003.

SILVEIRA, M.L.A.; ALLEONI, L.R.F.; GUILHERME, L.R.G. Biosolids and heavy metals in soil. Scientia Agricola, v.60, p.793-806, 2003.

SILVEIRA, M.L.A.; ALLEONI, L.R.F. Copper adsorption in tropical Oxisols. Brazilian Archives of Biology and Technology, v.46, p.529536, 2003.

SILVEIRA, M.L.A.; ALLEONI, L.R.F.; CASAGRANDE, J.C.; CAMARGO, O.A. Energia livre da reação de adsorção de cobre em Latossolos ácricos. Scientia Agricola, v.56, p.1117-1122, 1999.

SILVEIRA, M.L.A.; ALLEONI, L.R.F.; CAMARGO, O.A.; CASAGRANDE, J.C. Copper adsorption in oxidic soils after removal of organic matter and iron oxides. Communications in Soil Science and Plant Analysis, v.33, p.3581-3592, 2002.

SIMONETE, M.A.; KIEHL, J.C. Extração e fitodisponibilidade de metais em resposta à adição de lodo de esgoto no solo. Scientia Agricola, v.59, p.555-563, 2002.

SOIL SURVEY STAFF. Keys to soil taxonomy. 4. ed. Blacksburg: Crop and Soil Environmental Science Department, 1990. 423p. (SMSS Technical Monography, 6).

SWIFT, R.S.; McLAREN, R.G. Micronutrient adsorption by soils and soil colloids. In BOLT, G.H.; BOODT, M.F.; HAYES, M.H.B.; McBRIDE, M.B. (Ed.) Interactions at the soil colloid-soil solution interface. Dordrecht: Kluwer Academic Publications, 1991. cap.9, p.257-292.

TEMMINGHOFF, E.J.M.; SJOERD, E.A.T.M.; ZEE, V.; KEIZER, M.G. The influence of $\mathrm{pH}$ on the desorption and speciation of copper in a sandy soil. Soil Science, v.158, p.398-408, 1994.

UEHARA, G. Acric properties and their significance to Soil classification. In: INTERNATIONAL SOIL CLASIFICATION WORKSHOP, 5., Rio de Janeiro, 1986. Proceedings. Rio de Janeiro: EMBRAPA, SNLCS, 1988. p.19-22.

WANG, S.Q.; ZHOU, D.M.; WANG, Y.J.; CHEN, H.M. Effect of ophenylenediamine on $\mathrm{Cu}$ adsorption and desorption in red soil and its uptake by paddy rice (Oryza sativa). Chemosphere, v.51, p.77-83, 2003.

WU, J.; LAIRD, D.A.; THOMPSON, M.L. Sorption and desorption of copper on soil clay components. Journal of Environmental Quality, v.28, p.334-338, 1999. 
YIN, Y.; IMPELLITTERI, C.A.; YOU, S.J.; ALLEN, H.E. The importance of organic matter distribution and extract soil:solution ratio on the desorption of heavy metals from soils. The Science of the Total Environment, v.287, p.107-119, 2002.

ZELAZNY, L.W.; HE, L.; VANWORMHOUDT, A. Charge analysis of soils and anion exchange. In: SPARKS, D.L.; PAGE, A.L.; HELMKE, P.A.; LOEPPERT, R.H.; SOLTANPOUR, P.N.; TABATABAI, M.A.; JOHNSON, C.T.; SUMNER, M.E. (Ed.) Methods of soil analysis: chemical methods. Madison: SSSA, 1996. cap.3, p.1231-1253.
ZHU, B.; ALVA, A.K. Differential adsorption of trace metal by soils as influenced by exchangeable cations and ionic strength. Soil Science, v.155, p.61-66, 1993.

Received April 04, 2003

Accepted February 12, 2004 